Proceedings

\title{
Sustainable Urban Mobility Plans In Spain. A Critical Analysis
}

María-José Márquez-Ballesteros ${ }^{* *}$, and Daniel Navas-Carrillo ${ }^{2,}$

\author{
1 University of Malaga. Department of Art and Architecture; mjmarquez@uma.es \\ 2 University of Seville. Department of Urban and Regional Planning; dnavas@us.es \\ * Correspondence: mjmarquez@uma.es
}

Citation: Márquez-Ballesteros, M.J.; Navas-Carrillo, D., 2022, Sustainable urban mobility plans in Spain. A critical analysis. SUPTM 2022 conference proceedings sciforum054314 .

https://doi.org/10.31428/10317/10586

Publisher's Note: UPCT and Sciforum stays neutral with regard to jurisdictional claims in published maps and institutional affiliations.

Copyright: (c) 2022 by the authors. Submitted for possible open access publication under the terms and conditions of the Creative Commons Attribution (CC BY) license (https://creativecommons.org/license s/by/4.0/).

\begin{abstract}
This paper proposes to evaluate the Sustainable Urban Mobility Plans (SUMPs) of the sixteen most populated cities in Spain. They have consolidated as the main mobility planning instruments. Nevertheless, the research aims to assess its effectiveness and actual scope in responding to the challenges posed by the current policy and legal framework. A battery of indicators has been defined, grouped into four thematic sections: current and valid (1), conceptual approach (2), evaluation system (3) and awareness-raising actions (4). The document concludes by spotlighting relevant guidelines to establish a Sustainable Urban Mobility Plan.
\end{abstract}

Keywords: SUMP; Urban Mobility; Urban Strategic Planning; Urban Public Policy; Sustainability

\section{Sustainable Urban Mobility Plans in Spain}

Sustainable Urban Mobility Plans (SUMP) have been consolidated as planning instruments that bring together and coordinate all those actions to reduce the environmental impact of mobility. They are mainly urban in scope, although they can also be developed on a supra-municipal scale. In Spain, they are regulated by Law 2/2011 on Sustainable Economy [1]. However, they had already been included in Law 34/2007 on air quality and atmospheric protection [2], or the Energy Saving and Efficiency Strategy of 2004 [3]. This legislative development reflects the agreements adopted in the international sphere. For instance, the 1992 United Nations Framework Convention on Climate Change already included the need to plan and manage urban transport in the interests of greater efficiency and rationality in its use.

Law 2/2011 makes any aid or subsidy for urban or metropolitan public transport since 2014 conditional on drafting a Sustainable Mobility Plan. This document must at least include "a diagnosis of the situation, the objectives to be achieved, the measures to be adopted, the appropriate funding mechanisms and the procedures for monitoring, evaluation and review and an analysis of the economic, social and environmental costs and benefits" [1]. This obligation has been a critical factor in the proliferation of Sustainable Urban Mobility Plans in large Spanish cities and medium-sized ones. They are articulated to obtain funding rather than an end in themselves in most cases.This concern leads us to ask, beyond the quantitative data on the total number of plans approved, what effectiveness and real scope Sustainable Urban Mobility Plans currently have to achieve the objectives set and respond to the current urban challenges. Therefore, it is proposed to analyse the Sustainable Urban Mobility Plans of the 16 most populated cities in Spain: Madrid (2014) [4], Barcelona (2015, revised in 2019) [5], Valencia (2013) [6], Seville (2019 - diagnostic) [7], Zaragoza (2019) [8], Málaga (2012 - preliminar) [9], Murcia (2013) [10], Palma de Mallorca (2014) [11], Bilbao (2018) [12], Alicante (2013) [13], Córdoba (2013) [14], Valladolid (2015) [15], Vitoria (2007, revised in 2019) [16], La Coruña (2014) [17], and Granada (2013) [18]. 


\section{Assessment methodology}

The analysis seeks to discern the usefulness of these instruments through four dimensions. The first one focuses on the current relevance and validity as a strategic document, considering that many were approved before 2014. This section assesses whether they are based on an adequate analysis of the initial situation, provide a longterm vision, or propose regular monitoring and continuity in other municipal policies. The degree of development of their actions is also analysed.

The transversal role given to mobility hinders us from defining what we mean by Sustainable Urban Mobility. For this reason, the research tries to evaluate the conceptual approach of these documents, considering the steps taken in recent years in favour of strong sustainability and a more significant role for the social dimension. Consequently, this dimension seeks to analyse both the degree of intermodality, the scope of the participatory process and the inclusion of qualitative aspects. These aspects would allow overcoming a vision of mobility detached from urban planning and urban design and, therefore, providing a holistic view of the urban fact.

The assessment of the degree of effectiveness of these documents necessarily involves their own evaluation. As stipulated in Law 2/2011, SUMPs must include an evaluation section to identify deviations from the objectives and targets set during the life of the plan. Therefore, it is crucial to determine whether the proposed evaluation system allows demonstrating the degree of compliance and the benefits obtained with its implementation from a comprehensive approach. In this sense, it is equally necessary to establish quality evaluation mechanisms, if possible external, for greater transparency.

Finally, many of the mobility measures adopted, especially those aimed at reducing individual use of traditional combustion vehicles, require changes in the usual behavioral patterns of citizens. An appropriate dissemination and communication strategy since the beginning of the plan and throughout the process of developing and implementing can increase the degree of acceptance of their measures and, consequently, avoid its rejection. Besides, many of these measures require a profound socio-cultural transformation of our societies, so they should be accompanied by awareness-raising and sensitisation complementary actions beyond the plan.

Table 1. Assessment criteria grouped by dimension

\begin{tabular}{|c|c|c|}
\hline \multirow{5}{*}{$\begin{array}{l}\text { Current and } \\
\quad \text { valid }\end{array}$} & 1.1 & $\begin{array}{l}\text { Initial evaluation: degree of exhaustiveness of the data of the initial analysis, according to its nature and type of information } \\
\text { handled, key to establishing the priority lines of the Plan. }\end{array}$ \\
\hline & 1.2 & Long-term vision: timing, financing and prioritisation of the proposed actions, according to time elapsed since their approval. \\
\hline & 1.3 & Monitoring: review and reporting with revisions of targets and corrective actions where necessary. \\
\hline & 1.4 & Continuity: inclusion of its measures in other local actions or plans related to mobility. \\
\hline & 1.5 & Development: level of implementation of the proposed lines of action. \\
\hline \multirow{3}{*}{$\begin{array}{l}\text { Conceptual } \\
\text { approach }\end{array}$} & 2.1 & $\begin{array}{l}\text { Intermodality: balanced and integrated development of all modes of transport: public and private, passenger and freight, } \\
\text { motorised and non-motorised, moving and parking. }\end{array}$ \\
\hline & 2.2 & $\begin{array}{l}\text { Participatory process: transparent and participatory approach, involving key actors and stakeholders from the beginning and } \\
\text { throughout the process of developing and implementing the plan. }\end{array}$ \\
\hline & 2.3 & $\begin{array}{l}\text { Qualitative approach: analysis of qualitative and quality-related aspects of the measures, such as the technical conditions of } \\
\text { cycle paths, footpaths, and public transport infrastructure, the existence of secure bicycle parking areas, or the comfort and } \\
\text { safety of public transport journeys. }\end{array}$ \\
\hline \multirow{3}{*}{$\begin{array}{l}\text { Evaluation } \\
\text { system }\end{array}$} & 3.1 & $\begin{array}{l}\text { Scope: referring to the objectives and targets of the plan to demonstrate the degree of compliance through clear and easy to } \\
\text { understand indicators. }\end{array}$ \\
\hline & 3.2 & $\begin{array}{l}\text { Comprehensive assessment: assessment of the economic impact (review of costs and benefits according to the investment to be } \\
\text { made, economic growth, etc.), social impact (safety of pedestrians and cyclists, impact on health, etc.) or environmental impact } \\
\text { (air quality, energy consumption, etc.). }\end{array}$ \\
\hline & 3.3 & $\begin{array}{l}\text { Quality assessment: mechanisms to ensure quality and validate compliance with the Sustainable Mobility Plan in the medium } \\
\text { to short term, e.g., through external audits. }\end{array}$ \\
\hline \multirow{2}{*}{$\begin{array}{l}\text { Awareness } \\
\text {-raising } \\
\text { actions }\end{array}$} & 4.1 & $\begin{array}{l}\text { Dissemination and communication strategy: to encourage the transformation of different individual behaviours so that they } \\
\text { have an impact on the community as a whole. }\end{array}$ \\
\hline & 4.2 & Other awareness raising measures: measures included in other local actions related to mobility. \\
\hline
\end{tabular}




\section{Results}

As the following figure summarises, the response of the different plans analysed to the established criteria is uneven, with medium and low levels predominating in most cases. Four levels of achievement of the objectives described above have been set: high (3), medium (2), low (1) and null (0). The achievement of a conceptual approach based on intermodality, which is highly present in all the plans, at least in theory, stands out positively. A qualitative vision can be detected in the argumentation of most of the measures. However, in most cases, their implementation lacks this approach. All the plans define a process of citizen participation, although only three incorporate the main actors and stakeholders from the beginning and throughout the whole process of development and implementation of the plan. It is particularly worrying the generalised absence of dissemination and communication strategies and other mechanisms to raise awareness of sustainable mobility.

On the other hand, none of the plans incorporates mechanisms for evaluating the quality of the planning instrument itself. In general, although a long-term vision based on periodic monitoring is provided in most cases, the reality is that they do not mainly aspire to a comprehensive evaluation. At the same time, they constitute static documents that have not been revised, except in the case of Vitoria and Zaragoza and Barcelona, which is in the process of modification. Of the three, only the first one bases the revision on the previous document. Consequently, the continuity and, significantly, the degree of development of all of them are reduced to a minimum.

Table 2. Sustainable Urban Mobility Plan Assessment of the sixteen most populated cities in Spain

\begin{tabular}{|c|c|}
\hline & 1.1 \\
\hline Current & 1.2 \\
\hline and valid & 1.3 \\
& 1.4 \\
& 1.5 \\
\hline Conceptual & 2.1 \\
\hline approach & 2.2 \\
\hline & 2.3 \\
\hline Evaluation & 3.1 \\
\hline system & 3.2 \\
\hline Awareness & 3.1 \\
\hline -raising & 4.2 \\
\hline
\end{tabular}

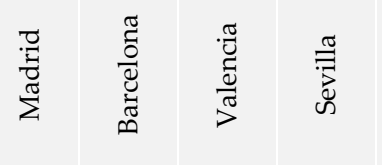
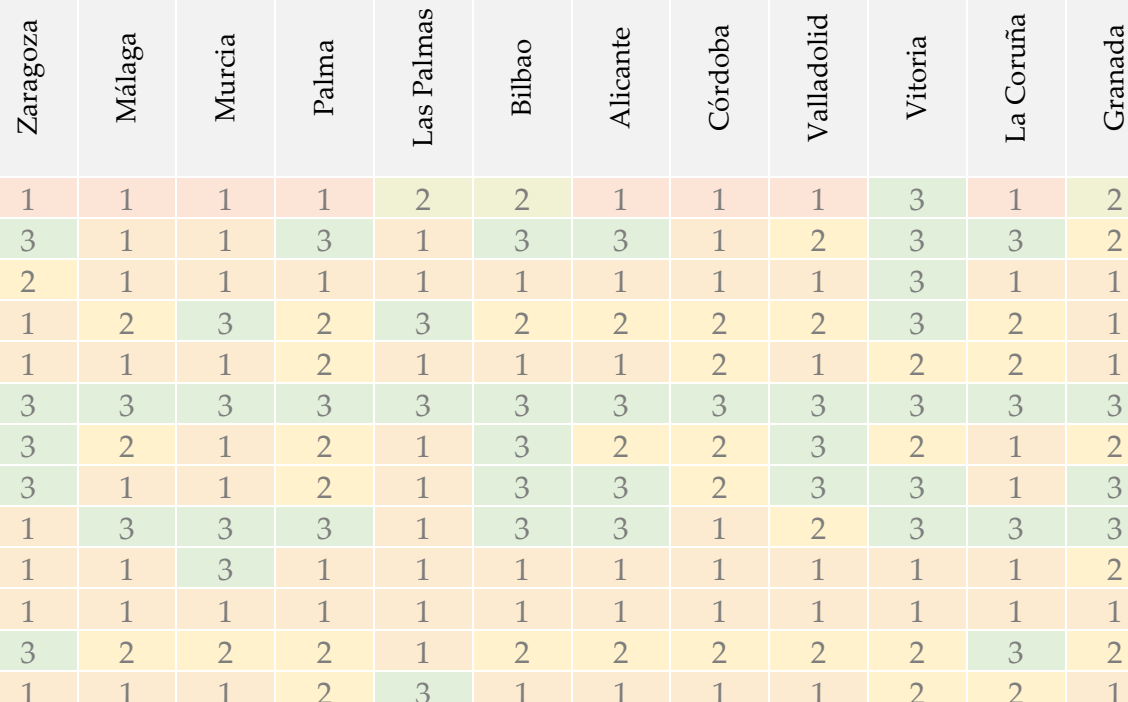

\section{Conclusions}

The ideal Sustainable Urban Mobility Plan could be the sum of all different dimensions selected from the best of each analysed city.

Table 3. Catalogue of good practices for planning sustainable urban mobility.

\section{OUTSTANDING PLAN}

1.1 Vitoria (2007 - rev. 2019)

\begin{tabular}{|l|c|c|}
$\begin{array}{c}\text { Current } \\
\text { and valid }\end{array}$ & 1.2 & Zaragoza (2019) \\
\hline 1.3 & Vitoria (2007 - rev. 2019) \\
\hline 1.4 & Las Palmas (2014) \\
\hline
\end{tabular}

Mobility and public space go ensemble and include social cohesion, urban greenery, compactness, or urban complexity goals.

Schedule, prioritisation of actions and budget for the implementation of measures according to short (2 years), medium (4 years) and long-term (8 years) horizons.

Review of the Sustainable Mobility and Public Space Plan for 2017, which in addition to an evaluation report, includes a participatory assessment.

Creation of a Mobility Observatory for evaluating mobility through a system of indicators 


\begin{tabular}{|c|c|c|c|}
\hline & 1.5 & None & $\begin{array}{l}\text { There are no tools to assess the degree of development-estimation of less than } 50 \% \text { plan } \\
\text { development-. Reduce the number of actions and scope with realistic proposals. }\end{array}$ \\
\hline \multirow{3}{*}{$\begin{array}{l}\text { Conceptua } \\
\text { l approach }\end{array}$} & 2.1 & All of them & $\begin{array}{l}\text { Generalised vision based on the balanced and integrated development of all modes and forms of } \\
\text { transport. Measures to improve intermodality conditions and accessibility to all of them. }\end{array}$ \\
\hline & 2.2 & Bilbao (2018) & $\begin{array}{l}\text { Open survey of social perception and developed via online form, social networks and WhatsApp. } \\
\text { Conference with stakeholders (initial phase). }\end{array}$ \\
\hline & 2.3 & Granada (2013) & $\begin{array}{l}\text { Analysis disaggregated by neighbourhoods and specific actions on urban space with detailed } \\
\text { analysis. A high degree of specificity of the proposals. }\end{array}$ \\
\hline \multirow{3}{*}{$\begin{array}{l}\text { Evaluation } \\
\text { system }\end{array}$} & 3.1 & Madrid (2014) & $\begin{array}{l}\text { Reference to the objectives and goals of the mobility plan to demonstrate its degree of compliance } \\
\text { through clear and easy-to-understand indicators. }\end{array}$ \\
\hline & 3.2 & Barcelona (2015 - rev. 2019) & $\begin{array}{l}\text { Generalised vision based on the balanced and integrated development of all modes and forms of } \\
\text { transport. Measures to improve intermodality conditions and accessibility to all of them }\end{array}$ \\
\hline & 3.3 & None & No mechanisms are incorporated to guarantee the quality of the Sustainable Mobility Plan. \\
\hline \multirow{2}{*}{$\begin{array}{c}\text { Awareness } \\
\text {-raising } \\
\text { actions }\end{array}$} & 4.1 & La Coruña (2014) & $\begin{array}{l}\text { Dissemination Plan. Preparation of a Guide of good practices for mobility and a manual on the } \\
\text { Design of Public Roads. }\end{array}$ \\
\hline & 4.2 & Las Palmas (2014) & $\begin{array}{l}\text { It contains awareness programs for schoolchildren development of a Didactic Unit on Sustainable } \\
\text { Urban Mobility and safe and responsible traffic courses. }\end{array}$ \\
\hline
\end{tabular}

Funding: This research takes place within the framework of Fundación Renovables and was funded by the Ministry for the Ecological Transition and the Demographic challenge, Government of Spain.

Acknowledgments: The authors gratefully acknowledge the support of the University of Malaga.

Conflicts of Interest: The authors declare no conflict of interest.

\section{References}

1. Ley $2 / 2011$, de 4 de marzo, de Economía Sostenible

2. Ley $34 / 2007$, de 15 de noviembre, de calidad del aire y protección de la atmósfera

3. Estrategia de Ahorro y Eficiencia Energética de 2004.

4. Ayuntamiento de Madrid (2014). Plan de Movilidad Urbana Sostenible de la ciudad de Madrid. Available online: https://www.madrid.es/portales/munimadrid/es/Inicio/Medio-ambiente/Plan-de-Movilidad-Urbana-Sostenible-de-la-ciudad$\underline{\text { de- }}$ Madrid/?vgnextfmt=default\&vgnextoid=d97a16c236694410VgnVCM2000000c205a0aRCRD\&vgnextchannel=3edd31d3b28fe41 0VgnVCM1000000b205a0aRCRD (accessed on

5. Ayuntamiento de Barcelona (2015). Plan de Movilidad Urbana de Barcelona. Available online: https://www.barcelona.cat/mobilitat/es/quienes-somos/plan-de-movilidad-urbana

6. Ayuntamiento de Valencia (2013). Plan Especial de Movilidad Urbana Sostenible de Valencia. Available online: http://www.valencia.es/ayuntamiento/trafico.nsf/vDocumentosTituloAux/13E8AC560711B1ADC1257C5B0041648A

7. Ayuntamiento de Sevilla (2019). Plan de Movilidad Urbana Sostenible del municipio de Sevilla. Diagnóstico. Available online: https://www.sevilla.org/actualidad/blog/plan-de-movilidad-urbana-sostenible-de-sevilla/pmus-sevilla-diagnostico v34.pdf

8. Ayuntamiento de Zaragoza (2019). Revisión del Plan de Movilidad Urbana Sostenible de Zaragoza. Available online: https://www.zaragoza.es/sede/portal/movilidad/plan-movilidad/

9. Ayuntamiento de Málaga (2012). Plan Especial de Movilidad Urbana de Málaga. Documento de Avance II. Available online: https://movilidad.malaga.eu/es/lineas-de-trabajo/plan-especial-de-movilidad-urbana-sostenible-pemus/

10. Ayuntamiento de Murcia (2013). Muévete. Plan de Movilidad Urbana Sostenible del municipio de Murcia. Available online: https://www.murcia.es/documents/11263/532202/PMUS+13-01-2014.pdf

11. Ayuntamiento de Palma de Mallorca (2014). Plan de Movilidad Urbana Sostenible de Palma de Mallorca. Available online: http://www.mobipalma.mobi/es/pla-mobilitat-urbana-sostenible-pmus/

12. Ayuntamiento de Bilbao (2018). Plan de Movilidad Urbana Sostenible de Bilbao. Available online: https://pmus.bilbao.eus

13. Ayuntamiento de Alicante (2013). Plan de Movilidad Urbana Sostenible de Alicante. Available online: https://www.alicante.es/es/documentos/plan-movilidad-urbana-sostenible-alicante-pmus

14. Ayuntamiento de Córdoba (2013). Plan de Movilidad Urbana Sostenible de Córdoba. Available online: https://pmus.cordoba.es/avancePMUS/avancePMUS.htm

15. Ayuntamiento de Valladolid (2015). Plan Integral de Movilidad Urbana, Sostenible y Segura de la Ciudad de Valladolid. Available online: https://www.pimussva.es

16. Ayuntamiento de Vitoria (2007). Plan de Movilidad y Espacio Público de Vitoria - Gasteiz. Available online: https://www.vitoria-gasteiz.org/wb021/was/contenidoAction.do?idioma=es\&uid= 5e2b2877 120d224e518 $7 \mathrm{fe} 7$

17. Ayuntamiento de La Coruña (2014). Plan de Movilidad Urbana Sostenible de A Crotuña. Available online: https://www.coruna.gal/movilidad/es/planes-y-programas/pmus/documentos

18. Ayuntamiento de Granada (2013). Plan de Movilidad Urbana Sostenible de Granada. Available online: http://www.movilidadgranada.com/pmus index.php 